\title{
Article
}

http://dx.doi.org/10.11646/phytotaxa.245.3.5

\section{Novitates neocaledonicae III: A new species of Citronella (Cardiopteridaceae) endemic to New Caledonia}

\author{
JÉRÔME MUNZINGER ${ }^{1} \&$ SÉBASTIEN LEVIONNOIS ${ }^{2}$ \\ ${ }^{I} I R D$, UMR AMAP, Laboratoire de Botanique et d'Écologie végétale appliquées, Herbier NOU, F-98848 Nouméa (Nouvelle-Calédonie) \\ et IRD, UMR AMAP, F-34000 Montpellier (France).email: jerome.munzinger@ird.fr \\ ${ }^{2}$ Université de Montpellier, UMR AMAP, F-34000 Montpellier (France).
}

\begin{abstract}
A new species of Cardiopteridaceae, Citronella hirsuta, endemic to the east-central part of New Caledonia's main island, Grande Terre, distinguished on the basis of morphological evidence, is described and illustrated. This new species is distinguished by its densely hirsute leaves, while the two others species of Citronella occurring in New Caledonia have glabrous leaves. Citronella hirsuta is restricted to ultramafic substrate, and only known from areas that are situated within mining concessions. A preliminarily IUCN conservation status of Endangered (EN) is proposed.
\end{abstract}

Keywords: Citronella, Cardiopteridaceae, Icacinaceae, New Caledonia, taxonomy

\section{Introduction}

Icacinaceae were treated in the Flore de la Nouvelle-Calédonie et Dépendances by Villiers (1980), with a total of three genera and four species recognized. More recently the family has been shown to be polyphyletic (Kårehed 2001; Stull et al. 2015) and as a consequence all the New Caledonian representatives were assigned to different families. Firstly, Apodytes E.Mey ex Arn. (1841: 155), a genus of $\sim 15$ species of the Old World tropics, ranging from Africa to Queensland (Mabberley 2008), was recently placed in Metteniusaceae, and is represented by a single species in New Caledonia, A. clusiifolia (Baill.) Villiers (1980: 160). Secondly, Gastrolepis Tiegh. (1897: 115), endemic to New Caledonia, is now placed in Stemonuraceae, where it comprises two species, G. austrocaledonica (Baill.) R.A.Howard. (1940: 481) and G. alticola Munzinger, McPherson \& Lowry (2008: 776). Finally, Citronella D.Don (1832: 243) belongs to Cardiopteridaceae and has two species in New Caledonia, viz. C. macrocarpa Hürl. (in Guillaumin 1964: 60) and C. sarmentosa (Baill.) R.A.Howard (1940: 475). Mabberley (2008) indicates that Citronella has a total of twenty-one species and is distributed from Malesia across the Pacific to tropical America, and that its members exhibit the Nozeran architectural model of (Hallé et al. 1978), which is uncommon.

Although Citronella is said to have glabrous leaves and petioles in New Caledonia according to the Flore (Villiers 1980), material with a distinct indument on the leaves and petioles was collected for the first time in 2004, suggesting that it represented an entity that was not seen by Villiers. Additional collections and morphological studies conducted over the last decade have clearly confirmed that this material represents a distinct entity. As well, all known Pacific species of Citronella are trees, except C. sarmentosa (Howard 1942); thus this shrubby taxon cannot be confused with any species outside the archipelago and is therefore considered as a new species, which we describe and illustrate here. An identification key of Citronella in New Caledonia is provided, and a preliminary IUCN status is proposed.

\section{Materials and Methods}

All material of Citronella with an indument on the leaves and petioles was received on loan from NOU and P, and was studied at MPU (herbarium acronyms follow Thiers 2015). It was compared with 13 specimens of C. macrocarpa and 40 specimens of $C$. sarmentosa from P and MPU, as well as with information presented in key publications dealing 
with the taxonomy of the genus (Howard 1940; Howard 1942; Villiers 1980; Smith 1985). Measurements and shapes of various features are based on the examination of herbarium material, while colours were observed in the field by the first author. For the preparation of the description provided below, material was examined using a Leica S6D binocular microscope and photos were taken in the field with a Nikon D70 camera mounted with a $60 \mathrm{~mm}$ macro lens. The risk of extinction assessment was conducted using the IUCN Red List criteria (IUCN 2012); AOO value was calculated by using the online "geocat" software "http://geocat.kew.org" (Bachman et al. 2011).

\section{Taxonomy}

Key to the species of Citronella in New Caledonia

1. Leaves and petioles with dense orange/golden hirsute indument; inflorescence densely hirsute with orange/golden trichomes $\sim 0.5$ mm in length (Fig. 1A).....

C. hirsuta

-. Leaves and petioles glabrous; inflorescence with appressed orange/golden or white/grey trichomes less than $0.5 \mathrm{~mm}$ long (Fig. 1B, C) .......

2. Domatia present on abaxial surface of leaves, blade chartaceous, apex acute, midvein on adaxial surface convex in proximal portion (leaves thus appearing conduplicate in pressed material); inflorescence with appressed white/grey indument; gynoecium subglobose to ellipsoid; large trees restricted to volcano-sedimentary substrate.

C. macrocarpa

-. Domatia absent on abaxial surface of leaves, blade coriaceous, apex usually distinctly acuminate; midvein on adaxial surface flat throughout its length (leaves thus appearing flat in pressed material); inflorescence with appressed orange/golden indument, gynoecium narrowly conical; a sarmentose shrub (or occasionally a small tree) on both ultramafic and volcano-sedimentary substrates.

C. sarmentosa

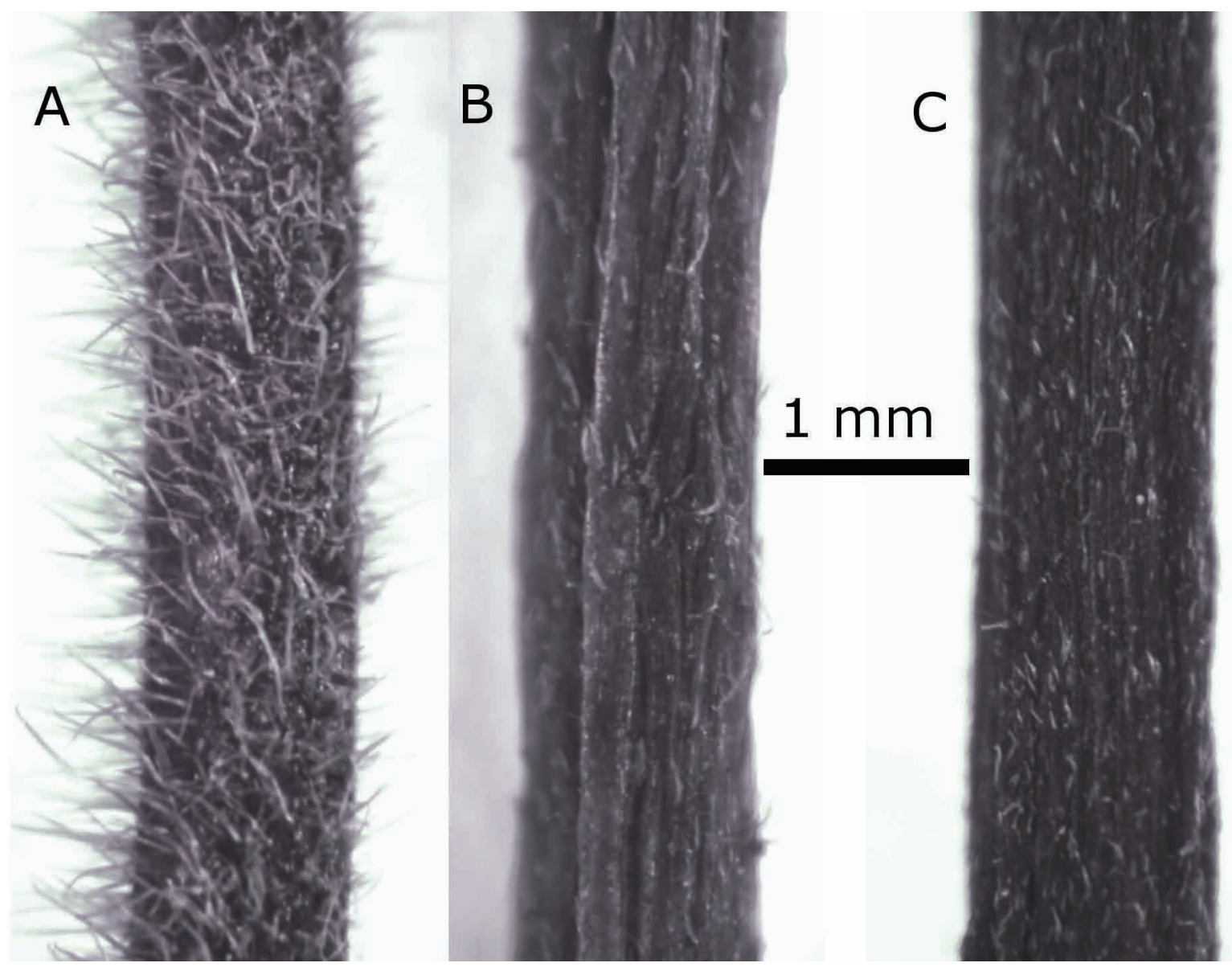

FIGURE 1. Comparison of trichomes on the inflorescence axes of the three species of Citronella occurring in New Caledonia. A. Citronella hirsuta. B. Citronella sarmentosa. C. Citronella macrocarpa. (A. Munzinger et al. 4045. B. McPherson 5470. C. MacKee 12894).

Note:-Three sheets in P (P04468794, P04468795 \& P04468796) that clearly belong to Citronella sarmentosa bear labels for MacKee 12882 indicating a tree $15 \mathrm{~m}$ tall. However, the specimen at NOU (NOU050651) of this same 
number is a species of Cunoniaceae, Geissois polyphylla Lécard ex Guillaumin (Guillaumin 1940: 244), as confirmed by Hopkins et al. (2014), and examination of MacKee's fieldbook reveals that the specimens at P were wrongly labeled and in fact correspond to MacKee 12881 (originally identified as "Sarcanthidion Baill."=Citronella), which is a $3 \mathrm{~m}$ tall shrub, corresponding to the habit of $C$. sarmentosa.

Note:-Lasianthera austrocaledonica Baill.(1873-1876: 193) was designated as the type species in the description of the genus Gastrolepis Tiegh. (1897: 116), but van Tieghem only implied the new combination and didn't clearly associated the final epithet with the new generic name; thus the combination is not valid following art. 35.2 (McNeill et al. 2012), and the correct citation is Gastrolepis austrocaledonica (Baill.) R.A.Howard (1940: 481).

Citronella hirsuta Munzinger, sp. nov. (Figs. 1A, 2 \& 3)

Type:-New Caledonia. Province Nord: Route Poro-Kouaoua, 21²2’24’'S, 16544’07’E, 17 December 2006, J. Munzinger, D., I. \& C. Létocart 4045 (Holotype P 00641022, Isotypes MO, MPU 026671, NOU 017285).

Diagnosis:- The new species resembles Citronella sarmentosa in lacking domatia on the abaxial surface of its leaves, in forming small shrubs, and in having terminal, erect inflorescences, but can be distinguished by the dense, persistent hirsute indument on its leaves, petioles and inflorescences axes, versus glabrous leaves and petioles, and short, appressed trichomes on the inflorescences axes in C. sarmentosa.

Shrub, up to $3 \mathrm{~m}$ tall, multi-stemmed. Bark dark brown. A hirsute indumentum of orange/golden trichomes $\sim 0.5$ $\mathrm{mm}$ long present on leaves, petioles, and inflorescences. Leaf blades homomorphic, 7-13 x 2-5 cm, lanceolate to ovate or oblong, base usually asymmetric, rounded to cuneate, margin revolute, apex acuminate, sometimes weakly so, abaxial surface densely pubescent, adaxial surface less so, midvein strongly convex on abaxial surface, concave on adaxial surface, secondary veins 4-7. Petiole canaliculate, pubescent, 7-10 (-15) $\mathrm{mm}$ long.

Inflorescence a raceme of scorpioid cymes, 3-20 cm long, axillary and terminal. Cymes 3-15 mm long, bearing up to 12 flowers. Bracts triangular, $1 \times 0.5 \mathrm{~mm}$, with black trichomes. Peduncle pubescent. Floral buds obovate, $3-4 \mathrm{x}$ 1.5-2 mm. Flowers pentamerous, bisexual. Sepals imbricate in bud, white, glabrous on both surfaces, $0.5-1.5 \times 0.5-1$ $\mathrm{mm}$, united at the base, margin usually ciliate with 0 to 5 long, orange/golden trichomes $\sim 0.5 \mathrm{~mm}$ long. Petals valvate $2 / 3$ of their length and imbricate at summit in bud, oblong, glabrous on both surfaces, white/light yellow to dark brown when dry, apex of each petal twisted, 1.5-3 mm long, base $0.5-1 \mathrm{~mm}$ wide, distal half 1-2 mm wide, early caducous. Stamens 5, glabrous, filaments $2-3 \mathrm{~mm}$ long, anthers $\sim 1 \mathrm{~mm}$ long. Gynoecium glabrous, conical, ovary $0.5 \times 1.5 \mathrm{~mm}$, style 1.5-2.5 mm long, stigma two-lobed, blackish (in herb.). Fruit a drupe, 1-2 x $0.5-1 \mathrm{~cm}$ when dry (in herb., only immature known), ellipsoid, glabrous, dark brown/black when dry (in herb.). Seeds not seen.

Phenology:-Flowers of Citronella hirsuta have been observed in December and February, and immature fruits have been collected in April.

Distribution and Ecology:-This new species is only known from the east-central part of New Caledonia's main island, Grande Terre, in North Province (Fig. 3), where it occurs in thalweg (gully) forest and dense maquis vegetation on ultramafic substrate, at around 200 meters elevation. Only five adult individuals are known but intensive field prospection in the area could potentially locate other individuals.

Etymology:- The plant is named based on the unique nature of its indumentum among New Caledonian Citronella species.

Species recognition:-Even sterile, individuals of Citronella hirsuta can easily be distinguished from its New Caledonian congeners by its unique hirsute indument of orange/golden trichomes found on the leaves, including both the petiole and blade, as well as the inflorescence. Citronella hirsuta also differs from C. macrocarpa by lacking domatia on the abaxial surface of its leaves, and the fact that it is a small shrub, rather than always having at least one domatium in the axil of a secondary vein where it joins the midvein (and sometime also between secondary and tertiary veins), and in being a large tree up to $40 \mathrm{~cm}$ in diameter that has been exploited for its wood (in Sarlin 1954, confused with $C$. sarmentosa at that time; $C$. macrocarpa was published 10 years later). All three New Caledonian species of Citronella have indument on their inflorescences but in C. sarmentosa and C. macrocarpa the trichomes are scattered and appressed (Fig. 1B, C), whereas in C. hirsuta they are numerous and erect (Fig. 1A). Moreover, C. sarmentosa and C. hirsuta have erect, terminal inflorescences (in addition to accessory axillary inflorescences) with orange/golden trichomes, whereas C. macrocarpa has long, pendant, ramiflorous inflorescence with white/grey trichomes. The petiole of $C$. hirsuta also differs in generally not exceeding $1 \mathrm{~cm}$ long, whereas $C$. sarmentosa and C. macrocarpa have a petiole that measures 1-2 cm long. The subglobose to ellipsoid ovary with its very short style distinguishes C. macrocarpa from C. hirsuta and C. sarmentosa, which have an ovary and style forming a slender 
structure whose parts are difficult to distinguish. Two stigmas can be distinguished on the styles of $C$. hirsuta and $C$. macrocarpa, whereas there is only a single stigma in C. sarmentosa.

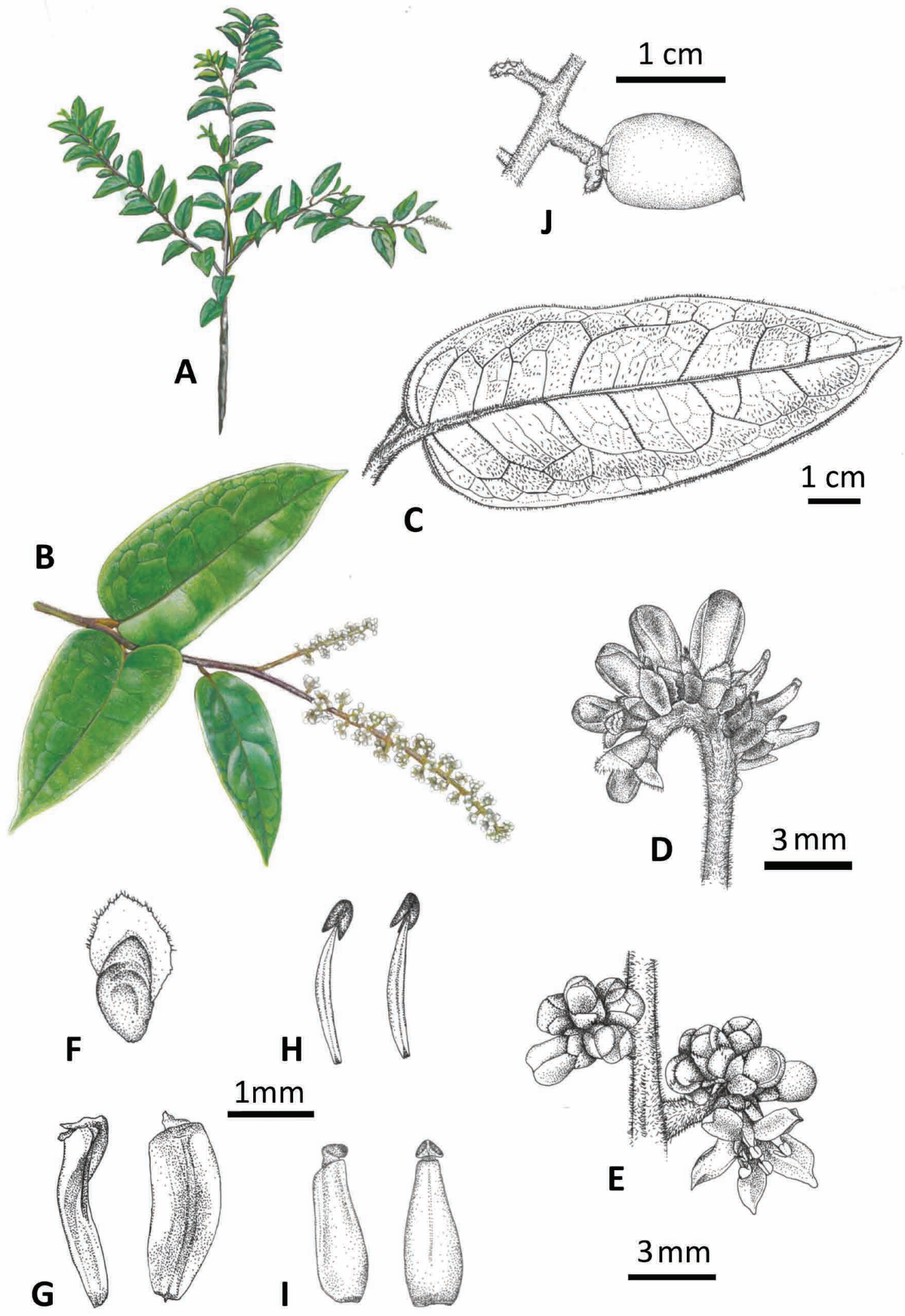

FIGURE 2. Citronella hirsuta. A. Habit. B. Leaves and inflorescence. C. Hirsute leaf. D. Scorpioid cyme. E. Part of an inflorescence with an open flower. F. Sepal. G. Petal . H. Stamen. I. Gynoecium. J. Fruit. Drawn by Laurence Ramon from Dagostini \& Rigault 805, Munzinger \& Chapelle 4364, field pictures by JM (for A \& B). 
Conservation status:- The plant is only known from 2 subpopulations, both located within mining concessions (Fig. 3) belonging to two different mining companies. Thus, the two subpopulations are considered as two distinct locations (sensu IUCN). The AOO calculated is $27 \mathrm{~km}^{2}$. In the case of the Bota Mere specimen, the area was the focus of a botanical inventory for possible future mining activities. Citronella hirsuta is assigned a preliminary conservation status of Endangered (EN B2 a,b(iii)) using the IUCN Red List criteria (IUCN 2012).

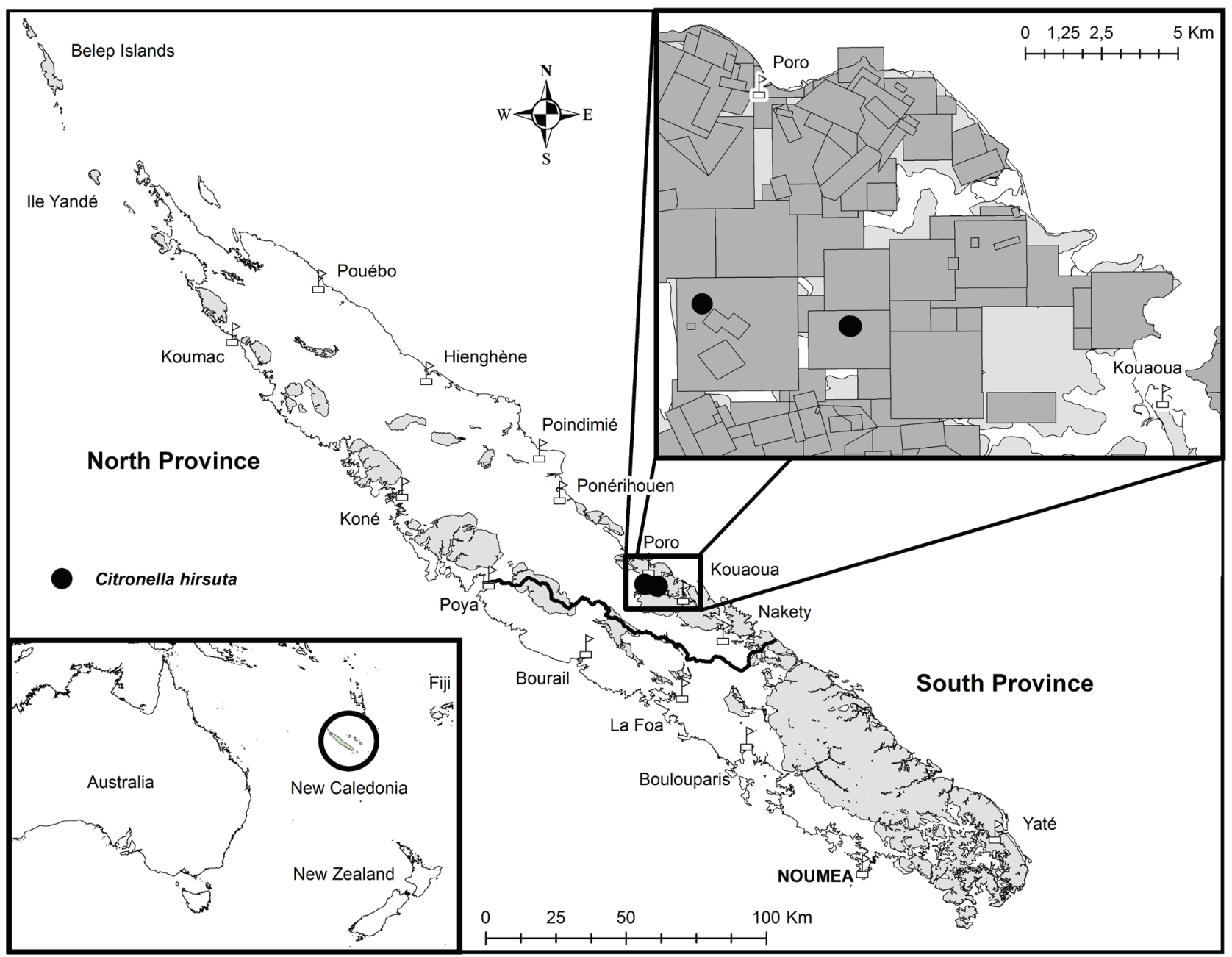

FIGURE 3. Distribution of Citronella hirsuta. Pale grey represents areas with ultramafic substrates, the black line shows the border between the North and South Provinces, and dark grey (inset) represents mining concessions (C SMC/DIMENC) in the area where the species occurs.

Additional specimens examined (Paratypes):-New Caledonia, North Province, Col de Poro (Bota Mere), 21 22 '00.42”S, 16541'30.77’'E, 10.II.2004 (fl.), Dagostini \& Rigault 805 (NOU015205, NOU054724); Kouaoua, plateau, 25.VII.2005 (st.) [same individual as JM4045], Munzinger 2952 (NOU008019, P05250578, P05250579); Route de Poro, 21²2’24.31’S, 16544'9.17’E, 6.IV.2007 (young fr.), Munzinger \& Chapelle 4364 (NOU017767).

\section{Acknowledgements}

We thank Laurence Ramon for her fine illustration, the curators of P and NOU for the loan of specimens and the curator of MPU for permission to work in the collections, SMC/DIMENC for authorization to use "cadastre minier". Thanks to Frédéric Rigault for help with locating his collection, Jérémy Girardi (NOU) for scanning specimens, and Grégoire Flament (P) for assistance with MacKee's collections. Thanks to Pete Lowry for help in translating, and comments on an earlier version of this manuscript. Collecting permit was provided by the North Province of New Caledonia. Thanks to an anonymous reviewer, Gordon McPherson and Marco Duretto for useful comments. 


\section{References}

Arnott, G.A.W. (1841) Notes on some South African plants. Hooker's Journal of Botany 3.

Bachman, S.P., Moat J., Hill, A.W., de la Torre, J. \& Scott, B. (2011) Supporting Red List threat assessments with GeoCAT: geospatial conservation assessment tool. In: Smith V, Penev L (Eds) e-Infrastructures for data publishing in biodiversity science. ZooKeys 150: $117-126$.

http://dx.doi.org/10.3897/zookeys.150.2109

Don, D. (1832) On the character and affinities of certain genera, chiefly belonging to the flora Peruviana. The Edinburgh New Philosophical Journal 13: 233-244.

Guillaumin, A. (1940) Matériaux pour la Flore de la Nouvelle-Calédonie. LVI : Révision des Cunoniacées. Bulletin de la Société Botanique de France 87: 242-256. http://dx.doi.org/10.1080/00378941.1940.10836417

Guillaumin, A. (1964) Résultats scientifiques de la mission Franco-Suisse de botanique en Nouvelle-Calédonie (1950-1952) III. Mémoires du Muséum National d'Histoire Naturelle, Sér. B, Botanique 15: 1-96.

Hallé, F., Oldeman, R.A.A. \& Tomlinson, P.B. (1978) Tropical trees and forests: an architectural analysis. Springer-Verlag, Berlin. http://dx.doi.org/10.1007/978-3-642-81190-6

Hopkins, H.C.F., Pillon, Y. \& Hoogland, R.D. (2014) Cunoniaceae. In: Poncy, O. (Ed.) Flore de la Nouvelle-Calédonie 26. Muséum National d'Histoire Naturelle - Institut de Recherche pour le Développement. Paris, pp. 1-455

Howard, R.A. (1940) Studies in the Icacinaceae, I, preliminarly taxonomic notes. Journal of the Arnold Arboretum 21: 461-489.

Howard, R.A. (1942) Studies in the Icacinaceae, V. A revision of the genus Citronella D. Don. Contributions from the Gray Herbarium of Harvard University 142: 60-89.

IUCN (2012) IUCN Red List Categories and Criteria: Version 3.1. Second edition. IUCN Species Survival Commission, IUCN, Gland, Switzerland and Cambridge, UK.

Kårehed, J. (2001) Multiple origin of the tropical forest tree family Icacinaceae. American Journal of Botany 88: 2259-2274. http://dx.doi.org/10.2307/3558388

Mabberley, D.J. (2008) Mabberley's plant-book, a portable dictionary of plants, their classifications, and uses. 3 edn. Cambridge University Press, Cambridge.

McNeill, J., Barrie, F.R., Buck, W.R., Demoulin, V., Greuter, W., Hawksworth, D.L., Herendeen, P.S., Knapp, S., Marhold, K., Prado, J., Prud'homme, van Reine F., Smith, G.F., Wiersema, J.H. \& Turland, N.J. (Eds.) (2012) International Code of Nomenclature for algae, fungi, and plants (Melbourne Code), adopted by the Eighteenth International Botanical Congress Melbourne, Australia, July 2011. Regnum Vegetabile 154. Koeltz Scientific Books, Koenigstein.

Munzinger, J., McPherson, G. \& Lowry II, P.P. (2008) A second species in the endemic New Caledonian genus Gastrolepis (Stemonuraceae) and its implications for the conservation status of high-altitude maquis vegetation: coherent application of the IUCN Red List criteria is urgently needed in New Caledonia. Botanical Journal of the Linnean Society 157: 775-783.

Sarlin, P. (1954) Bois et forêts de la Nouvelle-Calédonie. Centre Technique Forestier Tropical, Nogent-sur-Marne.

Smith, A.C. (1985) Flora Vitiensis Nova, a new flora of Fiji (Spermatophytes only). Pacific Tropical Botanical Garden, Lawai, Kauai, Hawaii.

Stull, G.W., Duno de, S.R., Soltis, D.E. \& Soltis, P.S. (2015) Resolving basal lamiid phylogeny and the circumscription of Icacinaceae with a plastome-scale data set. American Journal of Botany 102: 1794-1813. http://dx.doi.org/10.3732/ajb.1500298

Thiers, B. (2015) [continuously updated] Index Herbariorum: a global directory of public herbaria and associated staff. Available from: http://sweetgum.nybg.org/ih/ (accessed 22 January 2016)

van Tieghem, P. (1897) Sur les phanérogames sans graines, formant la division des inséminées. Bulletin de la Société Botanique de France 44: 99-139.

http://dx.doi.org/10.1080/00378941.1897.10830749

Villiers, J.-F. (1980) Icacinacées. In: Aubréville, A. \& Leroy, J.-F. (Eds.) Flore de la Nouvelle-Calédonie et Dépendances 9. Muséum National d'Histoire Naturelle. Paris, pp. 159-174. 